Turkey's Kurdish Conflict: Changing Context, and Domestic and Regional Implications Author(s): Murat Somer

Source: Middle East Journal, Vol. 58, No. 2 (Spring, 2004), pp. 235-253

Published by: Middle East Institute

Stable URL: http://www.jstor.org/stable/4330003

Accessed: 13-06-2017 11:11 UTC

JSTOR is a not-for-profit service that helps scholars, researchers, and students discover, use, and build upon a wide range of content in a trusted digital archive. We use information technology and tools to increase productivity and facilitate new forms of scholarship. For more information about JSTOR, please contact support@jstor.org.

Your use of the JSTOR archive indicates your acceptance of the Terms \& Conditions of Use, available at http://about.jstor.org/terms

Middle East Institute is collaborating with JSTOR to digitize, preserve and extend access to Middle East Journal 


\title{
Turkey's Kurdish Conflict: Changing Context, and Domestic and Regional Implications
}

\author{
Murat Somer
}

This article develops new analytical categories that are necessary to analyze Turkey's Kurdish conflict in its changed domestic and international environments and to evaluate the policy options. If Turkish state policies and discourse, and that of the other regional and international actors, signal to Kurds that the Turkish and Kurdish identities are mutually exclusive categories with rival interests, radical shifts may occur in Turkish Kurds' social and political identities and preferences. If state policies promote these identities as complements with compatible interests, radical shifts are unlikely and Turkey can play a more constructive regional role.

$\mathrm{D}$ uring the 1990s, Turkey witnessed the rising consciousness and politicization of the Kurdish identity, the surging visibility of the Kurdish category within the mainstream public-political discourse, and the ascent of Turkish nationalism that viewed the Kurdish rebel movement, the Kurdistan Worker's Party (PKK), and Kurdish nationalism in general, as the major antagonists. ${ }^{1}$ After Öcalan, the PKK's leader, was captured in 1999, the diminishing threat to state security by Kurdish separatism and the pull of the EU in a context of democratization further changed the domestic environment of Turkey's Kurdish conflict. ${ }^{2}$ The PKK renamed itself the Kurdistan Freedom and Democracy Congress (KADEK), and armed clashes between the state

Murat Somer is Assistant Professor of International Relations, Koç University, Sariyer, 34450, Istanbul, Turkey. E-mail: musomer@ku.edu.tr. The author would like to thank Dan Chirot, Necat Erder, Robert Hislope, Ahmet Içduygu, Resat Kasaba, Fuat Keyman, Kemal Kirisçi, Timur Kuran, Joel Migdal, Eliz Sanasarian, Baki Tezcan, Sezgin Tüzün, and Hakan Yavuz for valuable comments, criticisms, and supply of data, and to thank Burcu Sahin for superb research assistance. A Mellon post-doctoral fellowship at the Jackson School of International Studies at the University of Washington, Seattle was very helpful in developing the argument. The usual disclaimer applies.

1. Martin van Bruinessen, "Shifting National and Ethnic Identities: the Kurds in Turkey and Europe," in Günay Göksu Özdogan \& Gül Tokay, eds., Redefining the Nation, State and Citizen (Istanbul: Eren, 2000), pp. 91-108; Philip Robins, “Turkey and the Kurds: Missing Another Opportunity?" in Morton Abramowitz, ed., Turkey's Transformation and American Policy (New York: The Century Foundation Press, 2000), pp. 61-93; Resat Kasaba, "Kurds in Turkey: A Nationalist Movement in the Making," in Daniel Chirot and Martin E. P. Seligman, eds., Ethnopolitical Warfare: Causes, Consequences, and Possible Solutions (Washington, D.C.: American Psychological Association, 2001), pp. 163-177.

2. Öcalan is serving a life sentence since Turkey abolished the death penalty in 2002 . MIDDLE EAST JOURNAL ^ VOLUME 58, NO. 2, SPRING 2004 
forces and Kurdish rebels, which had continued since 1984 except for brief intervals, practically ceased. ${ }^{3}$

From 1998 to 2002, the percentage of Turkish citizens who viewed "terror and security" as the greatest threats to the country dropped from 39.3 to $5.5 \% .^{4}$ For the first time since the PKK revolt began in 1984, dynamics other than violence and considerations other than state security got a chance to play a significant role in determining the parameters of the conflict. The Parliament passed a series of laws granting significant cultural-linguistic rights to ethnic Kurds, such as broadcasting in and teaching Kurdish. These rights, whose implementation has so far been slow, were modest by world standards and fell short of politically conscious ethnic Kurds' expectations for change. Nevertheless, they were unprecedented steps forward for Turkey in the direction of the normalization of the Kurdish conflict via demilitarization and liberal democracy.

In 2003, the US-led war in Iraq and the ensuing uncertainties in that country drastically altered the external environment of the conflict. Iraqi Kurds represented by the KDP (Kurdistan Democratic Party) and PUK (Patriotic Union of Kurdistan) emerged as major US-allies and actors, while groups such as the PKK and Ansar alIslam, which the US government viewed as terrorists, remained active in the region. Northern Iraq borders Turkey's predominantly ethnic Kurdish Southeast. The possibilities of anti-Turkish or irredentist statehood for Kurds and of rising PKK activity in Northern Iraq refueled Turkish policy-makers' security concerns. New clashes occurred between the PKK fighters and the Turkish security forces inside Turkey; DEHAP, the Turkish-Kurdish party widely seen to be the PKK's political arm, organized mass protests that demanded, among other things, Öcalan's release. ${ }^{5}$ These circumstances increase the risk of renewed armed conflict between Turkey and the Kurdish nationalists. Such a conflict would strain Turkey's efforts to resolve its domestic Kurdish conflict through democratization and to build cooperative relations with Iraqi Kurds. These political and security risks have long been understood and expressed. ${ }^{6}$

Less understood are the ramifications for, first, the self-conceptions and political beliefs of large portions of Turkish Kurds, and, second, the mainstream Turkish society's perception of Kurds. These are certainly being affected, and will continue to be reshaped, by the developments in this new era, and will bear important implications for Turkey's domestic and external politics. As the sections ahead will show, the

3. For terminological simplicity, I will use the acronym PKK, by which the movement is best known, throughout this article.

4. Necat Erder, Türkiye'de Siyasi partilerin Yandas/Seçmen Profili (1994-2002) [Supporter/Voter Profiles of Political Parties in Turkey] (Istanbul: Tüses Yayinlari-Veri Arastirma, 2002), pp.17-18.

5. For example, "Dehap Members Close Road for Ocalan," and "PKK/KADEK's Curfew Order Ignored in Diyarbakir," Turkish Daily News, November 13 and October 10, 2003, respectively.

6. For an overview, Henri Barkey, "Hemmed in by Circumstances: Turkey and Iraq since the Gulf War," Middle East Policy, Vol. XII, No. 4 (October 2000), pp. 110-126; For the concerns of the Turkish military see interview with Chief of Staff Özkök by columnist M.A.Kislali, "Gen. Ozkok: Troubling Situation in Iraq," Turkish Daily News, November 10, 2003. 
first Gulf crisis (1990-91), and the Turkish state leaders' response to this changing security environment within a context of rising Kurdish nationalism at home and in Iraq, contributed to far-reaching shifts in the mainstream Turkish discourse regarding the Kurdish identity. The current period is similarly marked by rising Kurdish nationalism and uncertainty at Turkey's southern border, and may affect the mainstream Turkish discourse and beliefs regarding the Kurds.

Simultaneously, the current period features high expectations for change on the part of ethnic Kurds throughout the region. Combined with uncertainties about the future of Iraq and the Iraqi Kurds' status in it, and Turkey's democratization and prospects for joining the European Union, these circumstances impose various influences and constraints on the self-perceptions of Turkish Kurds. They fit the characteristics of periods of flux in David Laitin's analysis of ethnic and national group identity formation. In such periods of uncertain change, he argues, people's self-identities become prone to shift: they become especially responsive to state policy and discourse, to the "identity strategies" or projects offered by competing social-political leaders, to political-economic advantages of different identity strategies, and to ingroup and out-group social pressures. ${ }^{7}$ Such shifts in particular may occur in Turkey between binary and conglomerate understandings of Turkish and Kurdish identities. One cannot predict with certainty the timing and direction of such shifts, but one can examine the potential shifts under different scenarios. Then, one can ask how policies of state and non-state actors would affect the way the Kurdish identity or identities in Turkey may evolve under these scenarios, and analyze the implications for TurkishKurdish relations, and for Turkey's internal and external politics.

To do this requires new practical and analytical categories. In spite of the changed domestic and external contexts of Turkey's Kurdish conflict, practitioners as well as researchers continue to use the same analytical categories and explanations as before. In particular, three changes in the analysts' as well as practitioners' mental and discursive approaches to the Kurdish conflict would help to achieve an analytically more correct description and to generate more constructive policy implications. First, because Turks and Kurds do not constitute monolithic group categories with historically fixed identities, it is more appropriate to describe the political actors involved in the conflict as the representatives of various and changing visions of these identities, rather than as simply Turks and Kurds.

Second, the discursive-analytical distinction between ethnic and civic nationalisms, which is often used to explain the causes of the Kurdish conflict and to prescribe how to resolve it, needs to be replaced or complemented with new concepts. This distinction fails to describe which formulations of the Turkish and Kurdish identities would make them harmonious and inclusive, rather than conflicting and exclusive, in the new period. For example, it does not provide much insight into questions such as which policies would help to prevent Turkish-Kurdish polarization in Northern Iraq. Third, research should pay more attention to the regional and ideological diversity of

7. David Laitin, Identity in Formation: The Russian-Speaking Populations in the Near Abroad (Ithaca: Cornell University Press, 1998). 


\section{$238 \star$ MIDDLE EAST JOURNAL}

Kurdish identities and interests. By the same token, private-individual beliefs and interests regarding the Kurdish issue, as opposed to the security perceptions and interests of states and militant groups, should receive more attention. This is necessary to envisage the future of the Kurdish conflict under an optimistic scenario whereby Turkey's hopes to begin its negotiations for full membership in the EU materialize in 2005, and its relations with the Iraqi Kurds remain peaceful and cooperative. Under such a scenario, the articulation and aggregation of Kurdish interests within the Turkish political system would increasingly be shaped by the norms and institutions of identity politics à la Western European democracies. The relative importance of what ordinary Turks and Kurds think, and the influence of moderate groups and civil society organizations would increase accordingly. Alternatively, under a pessimistic scenario, Turkey's relations with the EU as well as Iraqi Kurds would deteriorate, and state security concerns and militant interests would once again monopolize the publicpolitical space.

\section{THE NEED FOR NEW CATEGORIES}

With the end of the Cold War that led to a surge of ethnic-communal conflicts during the first half of the 1990s, the causal relationships between ethnic identities and political conflict and violence became hot research topics. Since then, scholarly research has convincingly argued that there is no direct relationship between ethnic identities and conflict, for the following reasons. First, ethnic identities are not historically constant categories in conflict with each other; depending on the circumstances, they can serve inter-group cooperation as well. Second, they are not monolithic categories whereby inter-group divisions and conflicts of interest always override intra-group divisions and private-individual conflicts of interests. ${ }^{8}$ Third, to the extent that ethnic identities contribute to ethnic group conflicts, this occurs through causal mechanisms that shift the social constructions of these identities in such a way that a particular group becomes depicted as the "menacing other." 9

Thus, the essentialization of ethnic identities, that is, examining, talking, and writing about them as if they were static and monolithic categories in conflict with each other, is not only flawed analytically - it also has important practical consequences. Most importantly, it leads observers to overlook the intra-group divisions and conflicts that often drive actors' behavior. Frequently, the reasons the representatives of an ethnic group act aggressively toward another group have more to do with the purpose of gaining political ground vis-à-vis the moderates within their own group than actual antagonisms toward the other group. Here, instead of elaborating on these findings, I will discuss how dispassionate analysts should describe the group identities involved in the Kurdish conflict in light of these findings.

8. Stathis N. Kalyvas, "The Ontology of 'Political Violence': Action and Identity in Civil Wars," Perspectives on Politics, Vol.1, No. 3 (September 2003).

9. James D. Fearon and David D. Laitin, "Violence and the Social Construction of Ethnic Identity," International Organization, Vol. 54, No. 4, (Autumn 2000), pp. 845-877. 


\section{THE ESSENTIALIZATION OF THE KURDISH IDENTITY}

The essentialization of the Kurdish identity in public-political discourse serves the goals of hardliners, and it is frequently employed by social-political actors to undermine competitors, whether deliberately or as a political reflex. Hard-line Kurdish nationalists essentialize Kurdishness in order to strengthen their bid for nationhood and statehood. An ancient, historically continuous and monolithic image of Kurdishness facilitates the justification of these causes in the international arena. Further, the depiction of the Kurdish category in opposition to Turkishness vilifies and helps to weaken moderate Kurds who, in a more liberal environment, might prefer to cultivate both identities.

Hard-line Turkish nationalists focus on a sub-group of ethnic Kurds, Kurdish hardliners who oppose the legitimacy of the unitary Turkish state and political system, because the threat they pose to national security legitimizes heavy-handed state policies. These policies then generate a self-fulfilling prophesy: since moderate actors are more easily affected by these policies than hardliners, who tend to be better organized, the hardliners become overrepresented among the vocal supporters of Kurdish interests. ${ }^{10}$ Effective liberal-democratic institutions could change this outcome by providing equal opportunities for the articulation of a wider range of Kurdish views and interests. In this sense, the essentialization of the Kurdish identity can also be viewed as resulting from the relative weakness of Turkey's democratic institutions.

While political motives and institutional weaknesses thus contribute to the essentialization of the Kurdish identity, there is also a discursive reason. How would researchers and practitioners categorize ethnic Kurds who would like to cultivate a non-exclusive relationship between the Turkish and Kurdish identities, that is, one that enables people to embrace both? There are no social and scholarly consensuses on the precise meanings of terms such as ethnic Kurd, Turkish Kurd, or Kurdish-Turk, as in Italian-American. To make things even more confusing, is "Turkish" rather a composite identity, as in "British" and "American," or the derivative of an ethnic category, "Turk," that became the core of a national category, as in "English?"II "What we can't describe we can't explain," argues J. G. Ruggie. ${ }^{12}$ What cannot be described, cannot play a role in the public-political sphere either.

\section{THE ETHNIC DEFINITION OF THE TURKISH IDENTITY}

In order to provide a very brief historical account, both Turkish and Kurdish nationalisms were developed, in the modern sense of developing ideologies and collective actions pursuing a nation-state, by Ottoman-Muslim élites who were respond-

10. Murat Somer, "Ethnic Kurds, Endogenous Identities, and Turkey's Democratization and Integration with Europe," Global Review of Ethnopolitics, Vol. 1, No. 4 (June 2002), pp. 74-93.

11. For examples in the media, Murat Belge, "Türk Olmak Türkiyeli Olmak" ["Being Turkish and Being from Turkey"], Radikal, September 9, 2003.

12. "Territoriality and Beyond: Problematizing Modernity in International Relations," International Organization, Vol. 47, No. 1 (Winter 1993), pp. 139-174. 
ing to the Ottoman Empire's disintegration. ${ }^{13}$ They gained momentum during the period that spanned World War One, which led to the Ottomans' defeat and occupation; the War of Independence that followed it; and the years following the foundation of the Republic of Turkey in 1923.

Theoretically, and under different historical circumstances and élite choices, the resulting Turkish nationalism could have been more accommodating toward the Kurdish identity and more cooperative with Kurds. Kurds and Turks shared similar interests: since they were co-religionists, they belonged to the same socio-political category under the Ottoman system, that is, the same millet, and faced the same rival nationalisms, such as the Armenian and Greek nationalisms. Ethnic Kurds generally joined Turkish nationalists during the War of Independence, whereby they were won over by Turkish nationalists' appeal to the Muslim-Ottoman identity and recognition of Turkey's ethnic-cultural diversity. Kurdish élites were not all against the main cultural and social-political project that the ruling Kemalist regime adopted after the foundation of the republic; it has been observed that many representatives of Kurdish movements during the 1920 s and 1930 s had the same modernizing-westernizing zeal as the Kemalists. ${ }^{14}$

However, at this formative stage for both Turkish and Kurdish nationalisms, a conflictual rather than accommodative relationship developed between the two. Any plans for local-administrative autonomy in Kurdish areas dropped from the political agenda following the foundation of the republic, and the Turkish state nationalism and policies became increasingly exclusionary toward the Kurdish identity and assimilationist towards the Kurds after the 1925 Sheikh Said rebellion. ${ }^{15}$ By the end of the year, the government's actions clearly indicated that the expression of identities such as Kurd, Circassian, and Laz would be considered to be divisive. ${ }^{16}$ Until the 1990s, successive governments and the military continued to view ethnic particularism as a major threat to state security and to the "indivisible unity of the state and nation," although the nature and level of repressive state practices varied in accordance with the internal and external political developments.

In different forms and to differing degrees, various writers have attributed this outcome to ethnic-Turkish nationalism and have invoked the analytical distinction

13. For recent contributions, Hakan Özoglu, "Nationalism and Kurdish Notables in the Late Ottoman-Early Republican Era," International Journal of Middle East Studies, Vol. 33, No. 3 (August 2001), pp. 383-409; Tanil Bora ed., Milliyetçilik [Nationalism] (Istanbul: Iletisim Yayinlari, 2002). For nationalism as collective action, Michael Hechter, Containing Nationalism, (Oxford: Oxford University Press, 2000).

14. Hamit Bozarslan, "Kürd Milliyetçiligi ve Kürd hareketi (1898-2000)" ["Kurdish Nationalism and the Kurdish Movement, 1898-2000"], pp. 841-879 in Bora ed., Milliyetçilik. For the Kemalist modernization project and state discourse toward the Kurds, Mesut Yegen "The Turkish State Discourse and the Exclusion of Kurdish Identity," Middle Eastern Studies, Vol. 32, No. 2 (April 1996), pp. 216229.

15. Andrew Mango, “Atatürk and the Kurds,” Middle Eastern Studies, Vol. 35, No. 4, (1999), pp. 1 25.

16. Mango, "Atatürk and the Kurds," p. 20. 
between the ethnic and civic types of nationalism as remedies for the Kurdish conflict. ${ }^{17}$ Ethnic formulations tie membership in nation to assumed common ancestry, while civic formulations tie it to voluntary political association with the nation through citizenship, whereby shared territory, history, or religion may help to bond the citizens together. As the argument goes, in addition to secularization and political centralization, an ethnic formulation of Turkish nationalism caused the alienation of ethnic Kurds, as Turkishness, rather than less exclusionary categories such as territory and Islam, came to define the core of the Turkish state and citizenship.

The ethnic-civic nationalism distinction's explanatory and prescriptive usefulness is limited. In general, it is difficult to categorize national identities according to the ethnic-civic distinction because most national identities, including the French, which is a generic example of civic-territorial nationalism, and the Turkish are a mixture of both definitions. In pursuit of popular legitimacy via nation-building, nationalists, even the liberal kind, selectively draw on existing traditions and cultures, thereby privileging their contemporary carriers or claim-holders, intentionally or not. ${ }^{18}$

In relation to Turkey's Kurdish conflict, the major weakness of the ethnic nationalism argument is that, if the ethnic definition of Turkishness had been the main source of the conflict, it would have affected all non-Turkish Muslim ethnic groups in Turkey similarly. Turkey harbors dozens of such groups, some of which are quite large, such as the Alevis, Bosnians, Laz, Chechens, and Arabs. These groups' relationships with the state have been significantly less conflictual than that of the Kurds. In this regard, the economic dimensions of the Kurdish conflict, that is, the role of Eastern Turkey's deprivation vis-à-vis the rest of the country, require more attention, without downplaying the ethnic dimension of the conflict. ${ }^{19}$

Second, in order for the ethnic nationalism argument to be solid as an historical explanation, one would have to demonstrate that the ethnic definition of Turkish nationalism preceded, and was causally linked to, the development of Kurdish "counternationalism." Unless dispassionate historical research demonstrates that this was the case, it is more adequate to examine the Turkish and Kurdish nationalisms in a twoway relationship, whereby Turkish nationalism was hardened by the rise of Kurdish

17. Among others, David McDowall, The Kurds: A Nation Denied, (London: Minority Rights Group, 1992); Michael M. Gunter, The Kurds and the Future of Turkey, (New York: St. Martin's Press, 1997); M. Hakan Yavuz, "Five Stages of the Construction of Kurdish Nationalism in Turkey," Nationalism \& Ethnic Politics Vol. 7, No. 3 (Autumn 2001), pp. 2-24.

18. Among others, Günay Göksu Özdogan, "Civic versus Ethnic Nation: Transcending the Dual Model?" in Özdogan and Tokay, eds., pp. 37-57; Metin Heper, "Turkey, Yesterday, Today, and Tomorrow," Journal of Southeast European and Black Sea Studies, Vol.1, No. 3 (2001), pp. 1-19; Nergis Canefe, "Turkish Nationalism and Ethno-symbolic Analysis: the Rules of Exception," Nations and Nationalism Vol. 8, No. 2 (2002), pp. 133-155; Bernard Yack, "Nationalism, Popular Sovereignty, and the Liberal Democratic State" in T.V. Paul, G. John Ikenberry, and John A. Hall, eds., The Nation-State in Question (Princeton: Princeton University Press, 2003), pp. 29-50.

19. See Ahmet Içduygu, David Romano, and Ibrahim Sirkeci, "The Ethnic Question In An Environment of Insecurity: the Kurds in Turkey," Ethnic and Racial Studies Vol. 22, No. 6, (November 1999), pp. 991-1010. 
nationalism, and vice versa. In particular, we need a better understanding of the causes and impact of the Kurdish rebellions during the 1920s and 1930s. ${ }^{20}$

Third, the definition of Turkishness did not remain constant throughout the republican period. During the foundation of the republic, Turkishness acquired a new and more comprehensive meaning. It may be futile to look for consistency within the official definitions, and purpose and homogeneity among the élite formulations during this period because this was a period of transition and identity flux for the élites themselves. ${ }^{21}$ However, in general, as the meaning of Turkishness shifted from a relatively narrow ethnic group category to a national category, its content became more inclusive culturally and territorially. The ethnic definition of this new identity was accentuated by some groups within the ruling élites, and to some extent influenced the state policies, in certain periods such as the 1930s, when this occurred at least partly because of the ideological influence of the rising racism in Europe. Periods of military governments also witnessed the accentuation of the ethnic definition, as in the $1980-83$ period when a mixture of Sunni Islam and Turkish ethnonationalism was promoted ostensibly to curtail leftist-rightist polarization in society. Thus, the ethnic-civic distinction can have some merit in explaining the Kurdish conflict in some periods but less in others.

Whatever the virtues of the ethnic-civic distinction as a historical explanation, can a civic definition help to resolve the Kurdish conflict now? It is true that the accentuation of ethnicity in the state discourse and practices reinforces the alienation of some ethnically conscious Kurds, while probably also pressuring some other Kurds to assimilate further into Turkishness. It has been noted, for example, that the Turkish government's favorable treatment of ethnic Turks fleeing oppression in Bulgaria in 1989, in notable contrast to its treatment of the Kurds fleeing Iraq a year earlier, deepened many Turkish Kurds' sense of alienation and the social-political roots of the Kurdish conflict. ${ }^{22}$ However, there is no automatic relationship between an ethnic definition of a nation and a negative or suspicious depiction of the "ethnic other": a national group that defines itself ethnically can still be accommodating toward some or all ethnic minorities.

For example, an ethnic definition of Turkishness would not have prevented Turkish policy-makers from being more generous toward the Iraqi Kurdish refugees. Similarly, one can imagine Iraqi Kurds developing an ethnic notion of Kurdish nationalism yet also developing friendly relations with Turkey. This is because ethnic and antagonistic nationalisms are not the same, although ethnic nationalism is often used by political élites to induce aggressive nationalisms. To put it a little differently, creating an "other" may be part of the nature of nationalism, but the other is not always vilified.

Moreover, the civic definition is not necessary for, and does not ensure interethnic harmony. European democracies, such as Germany, France, and Britain have

20. Robert Olson, The Emergence of Kurdish Nationalism and the Sheikh Said Rebellion, 18801925 (Austin: University of Texas Press, 1989); also see Mango, "Atatürk and the Kurds."

21. For an overview, Kemal Kirisçi and Gareth M. Winrow, The Kurdish Question and Turkey: An Example of a Trans-state Ethnic Conflict (London: Frank Cass, 1997), pp. 89-103.

22. Bruinessen, "Shifting National and Ethnic Identities," pp. 95-98. 
relatively successfully managed and accommodated their ethnic-cultural diversity on the basis of national identities that widely diverge on the ethnic-civic scale. Consider also the example of the Yugoslav identity, which presumably fit the civic definition because one could become a Yugoslav through citizenship (and declare one's identity as Yugoslav in censuses) regardless of the ethno-national group to which one belonged. Nevertheless, during the 1980s, many Croats and Slovenians began to see Yugoslavness as clashing with their own identities and group interests. This occurred because they began to associate the Yugoslav identity with Serbian group interests, and positioned themselves in conflict with Serbs and with the institutions representing Yugoslavia.

Thus, defining Turkishness in civic terms would hardly guarantee lack of opposition toward Kurds. The ferocity of the conflict during the 1990s caused many Kurds to develop a hardened sense of their ethnic group identity vis-à-vis Turkishness, while reinforcing the bitterness of hard-line Kurdish nationalists. It would be naïve to think that they would embrace Turkishness and Turkish citizenship just because the state reformulates them in accordance with the civic definition. Turkish state leaders' earlier attempts to emphasize anayasal vatandaslik (constitutional as opposed to ethnically or culturally defined citizenship) in their discourse produced limited results in terms of reconciliation with politically mobilized Kurds. ${ }^{23}$ Similarly, the accentuation of an "Islamically shaped territorial identity" to contain Kurdish and Turkish ethnonationalism faces barriers. First, while common religious heritage and culture is a significant bond among Muslim ethnic groups in Turkey, the strategy of publicpolitical accentuation of it might deepen the secularist-Islamist and Sunni-Alevi cleavages. Second, it has been observed that Islamic writers of Turkish and Kurdish ethnicity often have competing goals; as a result, "rather than the Islamicization of ethnicity, the ethnicization of Islamic identity" occurred. ${ }^{24}$ Finally, given the EU's uncertain future relationship with Christianity and Islam, Turkey's accentuation of Islam may undermine its relations with the EU.

To sum up, the replacement of the supposedly ethnic Turkish-national identity with a civic-territorial or civic-religious identity is neither necessary nor sufficient for resolving the Kurdish conflict. In order for any identity strategy to be effectively unifying, socio-economic policies that actually create compatible interests for ethnic Turks and Kurds would have to accompany it.

\section{RIVAL AND COMPATIBLE DEFINITIONS OF IDENTITIES}

Identities become oppositional when they are defined according to what I call the rival definition, as opposed to the compatible definition. Table 1 summarizes their major characteristics. This conceptualization is more general and flexible than the ethnic-civic dichotomy because it emphasizes the subjective relationship between two

23. For example, Premier Demirel's recognition of "Kurdish Reality" in 1991.

24. M. Hakan Yavuz, "A Preamble to the Kurdish Question: The Politics of Kurdish Identity, Journal of Muslim Minority Affairs, Vol.18, No. 1 (1998), pp. 9-18, p.13. 
or more identity categories in actors' minds, instead of the specific way in which these identities are socially and politically constructed. It also can be applied to any group identity, including ethnic-national identities.

The rival definition refers to the beliefs of actors who consider two or more identity categories as rival substitutes and evaluate the associated group interests in zero-sum terms. Before his foundation of the AKP, which is Turkey's governing party which proclaims a significantly more liberal and democratic version of political Islam than its predecessors, Prime Minister Tayyip Erdogan had offered a stylized description of the rival definition with respect to Islam and secularism. Reportedly, in a 1993 speech he declared that "one cannot be both secular and Muslim. You will either be Muslim or secular. Brought together, these will repel each other."25 Accordingly, the rival definition compels people to make "either-or choices" between one or more identity categories, that is, if exit from one category and entry into another is considered acceptable by one's social and political environment. Otherwise, if mobility across categories is unavailable, as is often the case with the Roma (the so-called "gypsies") in Europe, the rival definition restricts people to one identity category.

By contrast, the compatible definition enables people to cultivate a sense of belonging to multiple identity categories. Thus, the compatible definition refers to the identity definitions held by people who perceive the identities in question as compatible complements and evaluate the associated group interests in positive-sum terms. In the earlier example, people holding the compatible definition would believe that they can simultaneously identify themselves as Muslim and secular. They would think that they can do this because they would believe that simultaneous association with both categories does not require holding contradictory self-conceptions or taking contradictory actions.

Martin van Bruinessen, a long-time authority on Kurds, appears to have stumbled on the compatible definition in the 1970s when talking to a villager in north-west Iran. The man baffled him by saying that he was, like his father, an Azeri, a Kurd and a Persian at the same time. ${ }^{26} \mathrm{He}$ also recalls people in Eastern Turkey who perceived themselves as Turks but spoke both Kurdish and Turkish. Bruinessen explained his observations as the result of assimilatory policies that led people who were "objectively" Kurds to forget their ethnic identity. However, they can also be explained by the prevalence of the compatible definition of the ethnic identities among the villagers. As Bruinessen observed, the villagers gave these identities, "linguistic, not ethnic

25. Hürriyet, July 7, 1998. Also see "The Case of Recep Tayyip Erdogan," parts I, II, and III, by Metin Heper, Turkish Daily News, February 5 through 7, 2002. Erdogan claimed that his words were distorted by the media.

26. Martin van Bruinessen, "Kurdish Society, Ethnicity, Nationalism and Refugee Problems," in Philip G. Kreyenbroek and Stefan Speri eds., The Kurds: A Contemporary Overview (London: Routledge, 1992), pp. 33-67. 
labels" in a modern sense.

TABLE 1. Rival and Compatible Definitions

\begin{tabular}{|c|c|c|}
\hline Type of Definition & Interest Relationship & Identity Relationship \\
\hline Rival Definition & $\begin{array}{l}\text { - Zero-sum relationship } \\
\text { - Oppositional }\end{array}$ & $\begin{array}{l}\text { - Substitutes } \\
\text { Binary choice between identities } \\
\text { - Low attachment to } \\
\text { comprehensive categories } \\
\text { that are jointly } \\
\text { belonged to }\end{array}$ \\
\hline Compatible Definition & $\begin{array}{l}\text { - Positive-sum relationship } \\
\text { - Complementary }\end{array}$ & $\begin{array}{l}\text { - Complements } \\
\text { Simultaneous holding of } \\
\text { identities } \\
\text { High attachment to compre- } \\
\text { hensive categories that are } \\
\text { jointly belonged to and to jointly } \\
\text { valued sources of belonging }\end{array}$ \\
\hline
\end{tabular}

The belief that the identities in question are mutually exclusive and the perception that the associated group interests are zero-sum are closely interrelated. However, it is worthwhile to note that the direction of causation seems to be a little stronger from the perceived interest relationship to the identity relationship than the other way around. ${ }^{27}$ Hence, a person who believes that two group identities are mutually exclusive can continue to think that the two groups have positive-sum interests. However, simultaneous holding of identities becomes troubling almost instantaneously when the groups in question are believed to have incompatible interests.

Imagine that powerful political actors in a diverse society begin to portray their groups as rival groups with conflicting interests. This would increase the expectation of potential inter-group conflicts and would compel people with multiple identities to choose one of their conflicting identities. To quote Laitin, "when the actions consistent with one identity [begin to] conflict with those of another identity held by the same person, as they do when the two identities [become] antagonistic groups on the political stage, people are compelled to give priority to one identity over the other." 28

A major reason why political actors may promote the rival definition is, as already argued, to undermine the moderate actors within their own ethnic group who promote cooperation and integration with the other groups in question. Another mo- 
tive may be to stem the assimilation of group members by making it impossible for them to identify with the culture and identity of the larger society. However, while succeeding in discouraging some group members from assimilation, this strategy of promoting the rival definition is a double-edged sword and can have unintended consequences. It can accelerate the assimilation of those group members whose willingness to integrate with the larger society is stronger than their in-group loyalty.

The most important effect of the rival definition is that it greatly facilitates the emergence of a "clashing definition," whereby the mutually exclusive and competitive other becomes also the "antagonistic other." ${ }^{29}$ For some actors this may be an unintended effect, while for others it is undoubtedly an unintended consequence, but the strengthening of the rival definition increases the polarization and likelihood of inter-group conflict in society.

\section{CHANGING PUBLIC DEFINITIONS OF THE KURDISH IDENTITY}

Until the 1990s, it was rare that people would publicly refer to "Kurds" in reference to an ethnic group in Turkey. The "Kurd" category was avoided in official documents as well as in the mainstream public-political discourse. The use of the word "Kurd" in the mainstream media can demonstrate this.

Mainstream newspapers preferred not to write about ethnic Kurds specifically, and if they had to, they avoided referring to any group within Turkey as Kurds. In 1984 and 1985, the mainstream daily Hürriyet published only 25 articles that could be identified as being related to ethnic Kurds in Turkey. Only three of these 25 articles, or $12 \%$, used the word "Kurd" one or more times. The discursive environment shifted mainly during 1991 and 1992. In these two years, Hürriyet published 658 articles related to Kurds within Turkey. Almost half of these, or 304 of them, used the word "Kurd" at least once. Compared to the 1984-1985 period, this indicates a twenty-sixfold surge in the number of articles and an almost four-fold rise in the portion of the articles making a reference to "Kurd." ${ }^{30}$

Figure 1 illustrates the rising frequency of "Kurd" from 1984 to 1993 . The lengths of the bars indicate the total monthly number of articles on issues related to ethnic Kurds. The darker portions correspond to the number of articles making a reference to the Kurd category. Until 1991, very few articles employed the word "Kurd," and their number was more or less independent from the total number of the articles on Kurds. Beginning in 1991, not only did the number of articles escalate drastically, but also a large percentage of the articles began to use "Kurd," indicating that the discursive categories that the journalists were using in describing similar events were in transition.

29. Murat Somer, "Cascades of Ethnic Polarization: Lessons from Yugoslavia," Annals of the American Academy of Political and Social Science, Vol. 573, (January 2001), pp.127- 151.

30. For consistency, articles on Kurdish organizations operating outside Turkey such as Europe and on refugees from Iraq, and the usage of "Kurdistan" as part of the name of the PKK were excluded because they do not necessarily indicate, from the perspective of the articles' authors, a reference to an ethnic group within Turkey. 
Within two years, the usage of terms such as "Kurd," "Kurdish," "Turk of Kurdish origin" or "Turkish Kurd" gained currency within the mainstream media and public conversation. President Demirel recognized the "Kurdish reality" toward the end of 1991. Today, a simple keyword search in the online sites of mainstream Turkish dailies easily brings up more than 2,000 articles containing "Kurd" in the last few years.

FIGURE 1. The Rising Visibility of the "Kurd" Category in Hürriyet

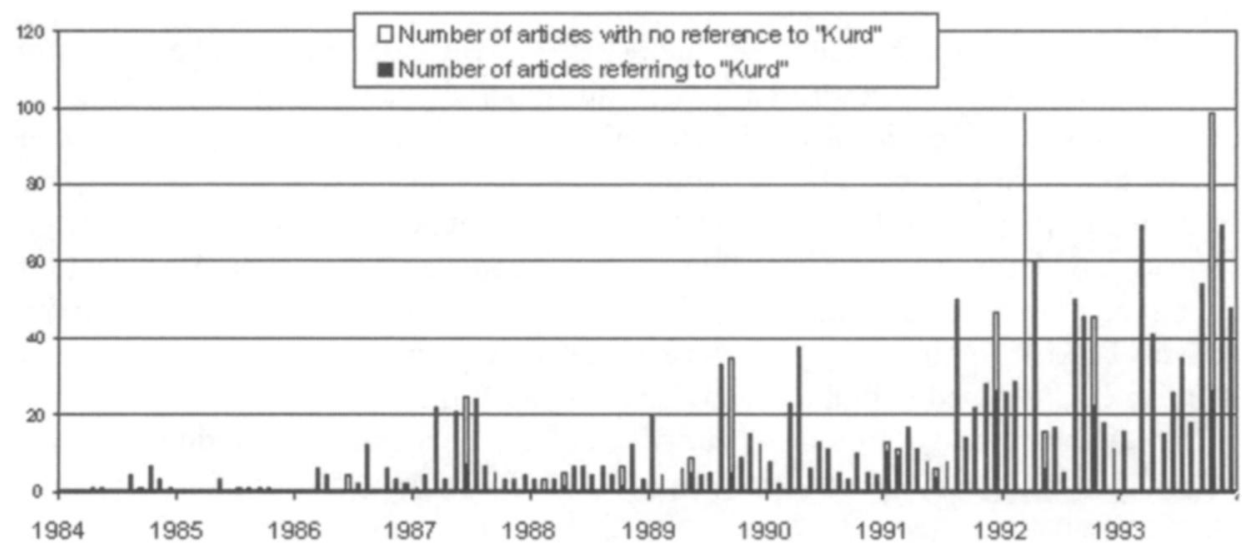

A full examination of why, how, and through which stages the mainstream discourse on Kurds changed is the subject of another article. Here, let me briefly discuss three implications that are important for the subject.

First, while the pre-1990s mainstream discourse reflected the oppression of the Kurdish identity and of ethnically conscious Kurds, it was also discouraging the development of a rival definition of Kurds and Turks. By comparison, the new mainstream discourse bears the potential of harboring the rival as well as the compatible definition because the increased visibility and currency of the Kurd category can facilitate the promotion of the former. This point requires some elaboration.

While there were diverse reasons why people avoided the Kurd category in the old discourse, partly it was because they did not see Kurds as any different from Turks. On one hand the avoidance of the term was caused by legal restrictions and social-political pressures. Turkey had strict laws against "ethnic separatism" and, in a political and judicial system that largely associated any sign of Kurdish (cultural or political) particularism with separatism, the price of being rightly or wrongly associated with Kurdish nationalism was high. But prevailing social-political norms against bölücülük (stirring up ethnic-religious divisions), were often sufficient to make mainstream actors self-control their public-political discourse. On the other hand, the absence of the Kurd category in the mainstream discourse resulted from voluntary association with the mainstream "melting pot" ideology, a type of state-founding nationalism rooted in élite fears of ethnic-religious plurality and fragmentation. This ideology entailed both inclusive and exclusive elements for Kurds. It excluded the Kurdish 
identity and culture from the public-political realm. But it was inclusive toward the Kurds insofar as it offered "conditional upward mobilization" for them: it allowed Kurds to join the mainstream society as long as they embraced the Turkish language and national identity and suppressed the public expression of their ethnicity. Many Kurds thus achieved high positions within the state without facing overt discrimination and being referred to as "different." In contrast, by pronouncing the difference and distinctiveness of Kurds, the new mainstream discourse can support the promotion of the rival or compatible perceptions of the Turks and Kurds, depending on the internal and external political developments.

Second, the first Gulf crisis, which closely preceded the discursive transformation in 1991-1992, appears to have been an important factor that contributed to it. Today, the security environment in Turkey's southeastern neighbor is similarly subject to uncertain change. The developments in Iraq during and after the first Gulf crisis made it impossible to ignore the Kurdish category. Considering a changing security environment in Northern Iraq and an ongoing PKK rebellion, President Özal attempted to initiate conciliatory moves toward Kurds as part of his plans for a more activist Turkish foreign policy in Northern Iraq. He "announced" that he was partly Kurdish. ${ }^{31}$ Combined with the need to accommodate the rising Kurdish radicalization in the Southeast, and a growing security threat that concerned and divided the political and economic élites, President Demirel followed Özal in recognizing the Kurdish identity.

Third, the fact that the Kurdish category gained currency so swiftly suggests that there was no significant opposition to it. The swiftness of the change can be explained by cascade theories of social-political change, which explain how the beliefs and public expressions of a society can change rapidly through chain reactions. Put simply, these theories maintain that rapid, surprising, and durable discursive shifts can occur when people do not oppose change on a private-identity level..$^{32}$ Otherwise, change can only occur gradually, over years. Cascade theories do not argue that private beliefs can, by themselves, explain social-political change, but that we should not ignore their role when explaining the transformation of public expressions of social identities.

In the Turkish case, the rapidity of the discursive change suggests that privateindividual beliefs might have played a role, even though the change itself appears to have been initiated by state actors. The content analysis reveals that the Kurd category was used by a marginal portion of articles even during the 1980s. Moreover, it was relatively freely used in reference to "external Kurds," as in the phrase "Iraqi Kurdish leaders," pointing to private-individual awareness of the Kurd category. This did not

31. "ABD Heyeti: Özal Bize Kürt Kökenliyim Dedi," ["The US-delegation: Özal Told Us That He Has Kurdish Background"] Hürriyet, October 10, 1989.

32. Timur Kuran, "Now Out of Never: The Element of Surprise in the East European Revolution of 1989," World Politics, Vol. 44, (October 1991), pp. 7-48; Susanne Lohmann, "The Dynamics of Informational Cascades," World Politics, Vol. 47, (October 1994), pp. 42-101; Gavin Wright, "The Civil Rights Revolution as Economic History," The Journal of Economic History, Vol. 59, No.2 (1999), pp. 267-289; Somer, "Cascades of Ethnic Polarization." 
necessarily translate to support for discursive change. But these observations suggest that, although people might have had strong norms against perceived bölücülük in a political sense, they had "soft beliefs" regarding the acceptance of the Kurdish category: they did not have firm ideological or cultural beliefs opposing its expression. ${ }^{33}$ This can partly explain the rapidity of the transformation that ensued.

\section{PRIVATE IDENTITIES}

Whatever their merit is in explaining social-political change, private beliefs and identities are not fixed themselves. They are subject to change over time. How will the developments in the current era affect the private identities and self-perceptions of Turkish Kurds? Reformulating this question in a more tractable form, to what extent can one expect major changes on an identity level, in response to internal and external developments such as Turkey's joining the EU or the materialization of Kurdish statehood in Northern Iraq?

In light of the above discussion and expressed simply, one can put forward the following. Insofar as Turkish Kurds hold diverse and conglomerate self-perceptions, and insofar as the state discourse and policies, and that of the influential domestic-external political actors and the media, reflect the rival definition, one can expect major changes in the self-perceptions of Turkish Kurds. Large shifts are unlikely insofar as ethnic Kurds hold monolithic and exclusively Kurdish self-perceptions, and the discourse and policies reflect the compatible definition.

Current estimates of ethnic Kurds in Turkey based on mother tongue, not subjective identification, range between 12 and $20 \%$ of Turkey's population. ${ }^{34}$ Evidence on subjective identification comes from separate surveys that are not methodologically or philosophically watertight, and from analysts' rule-of-thumb estimates. However, these are fairly consistent in two senses. First, the percentage of people exclusively identifying themselves as Kurdish lies within the 4-6\% range. Second, though ethnic Kurds form strong majorities in certain parts of the country, as a whole, they are a geographically dissipated group: between 50-60\% of ethnic Kurds are believed to live outside of Southeastern and Eastern Turkey, where they were traditionally concentrated. There are also significant religious, linguistic-cultural, and political divisions within Kurds. ${ }^{35}$

33. One should add that surveys also indicate lack of public support for ethnic-linguistic, educational and broadcasting rights. Erder, pp. 99-100.

34. Robins, pp. 62-63; Ayse Gündüz-Hosgör and Jeroen Smits, "Intermarriage between Turks and Kurds in Contemporary Turkey: Interethnic Relations in an Urbanizing Environment," European Sociological Review, Vol. 18, No. 4 (2002), pp. 417-432. National censuses stopped containing questions on mother tongue after 1965 .

35. Among others, Krisztina Kehl-Bodrogi, "Kurds, Turks, or A People In Their Own Right? Competing Collective Identities Among the Zazas," The Muslim World, Vol. 89, No. 3-4 (July-October, 1999), pp. 439-454; Bruinessen, "Shifting National and Ethnic Identities." 
Table 2 displays the results based on three sets of nation-wide surveys that were conducted in 1996, 2002, and 2003-2004. ${ }^{36}$ In these years, $9.24 \% 11.35 \%$, and $10.63 \%$ of all respondents, in respective order, declared themselves to be Kurdish: they marked "Kurd" as one of their identities from among a long list of ethnic, national, and religious categories known to exist in Turkey. Among these ethnic Kurds, however, 2.71\%, 5.76\%, and 5.20\%, or about one third in 1996 and a half in 2002 and 2003-2004, declared themselves exclusively as Kurdish, that is, they only marked "Kurd." The rest of the ethnic Kurds identified with Kurdishness in combination with other identity categories such as Sunni-Kurdish and Turkish-Kurdish. For the latter category of respondents, these identity categories seem to be important and compatible with each other.

Table 2 also includes the votes received by HADEP in 1995 and 1999 and by DEHAP 2002, two parties which are widely perceived to be ethnic-Kurdish and proPKK. ${ }^{37}$ It seems that these parties' voter support is roughly based in the share of the population exclusively identifying themselves as Kurds.

TABLE 2.

Kurdish Identity and Votes, Percentage of National

Exclusive / Composite Kurdish Identity

HADEP - DEHAP Votes

\begin{tabular}{cccccc}
1996 & 2002 & $2003-2004$ & 1995 & 1999 & 2002 \\
$2.71 / 9.24$ & $5.76 / 11.35$ & $5.43 / 10.63$ & 4.17 & 4.74 & 6.23 \\
\hline
\end{tabular}

Thus, the rival definition would compel about one half of Turkish Kurds to make hard choices between the ethnic and national, linguistic and territorial, and ethnic and religious components of their self-perceptions. Given the geographical dissipation of Kurds across Turkey, this can have destabilizing consequences for Turkey's social fabric. A massive strengthening of Kurdish nationalist sentiments at the expense of the Turkish identity and citizenship would please hard-line nationalist Kurds but would also incite and strengthen hard-line Turkish nationalists. Furthermore, the prevalence of the rival definition may cause hard-line Kurdish nationalists to radicalize in order to stem further assimilation of those Kurds who are integrated with the mainstream Turkish society. Efforts to resolve the Kurdish conflict within a context of liberal democracy, and hopes for a friendly and cooperative relationship between Turkey and Iraqi Kurds would be undermined accordingly.

By comparison, with the prevalence of the compatible definition, the potential is greater for further political liberalization and a more constructive Turkish foreign policy in the region. There would be less reason for Turkish nationalists to fear sig-

36. Erder. 1996 figures were taken and recalculated from the 1996 report of the same study. The yet unpublished 2003-2004 figures, which were collected in December 2003 through January 2004, were obtained from Necat Erder and Sezgin Tüzün at Veri Arastirma Research Organization, Istanbul. Election results can be accessed at the online site: http://www.secimsonucu.com.

37. Erder, pp. 93-98. Three-fourths in this national survey thought that HADEP was pro-PKK. 
nificant changes in Turkish Kurds' senses of belonging. Even though the developments in Iraq may lead to some strengthening of the Kurdish identity, radical shifts are unlikely because the compatible definition allows people to maintain multiple identities. Most Kurds would likely maintain composite identities. Outcomes that may please hard-line Turkish nationalists but concern Kurdish nationalists, such as massive assimilation into Turkishness, are also unlikely.

\section{POLICY IMPLICATIONS}

The current phase of Turkey's Kurdish conflict is momentous for the region. First, Turkey's chances of entering the EU will significantly increase if it can achieve a long-term resolution of its Kurdish issue by continuing and implementing its legalpolitical reforms in order to tackle its ethnic plurality via liberal democracy and economic development. Turkey would be the first EU country with a predominantly Muslim population and would be an example for other regional Muslim societies. It would also significantly increase the EU's credibility and political-economic weight as a global actor and as a social-political project, in the developing world in general and the Muslim world in particular. Second, the more Turkey can secure its relations with its citizens of Kurdish origin through democratic and developmental means, the less it would be threatened by Kurdish nationalism in Iraq and elsewhere. Hence, it would be able to shift its focus more easily to playing a more positive role in Middle Eastern affairs, such as by contributing to regional development and cooperation. Accordingly, democratization vis-à-vis the Kurdish identity and integration with the EU have facilitated a "striking shift in Turkey's position from a coercive to a benign or constructive regional power." ${ }^{38}$ But, it is far from clear that these positive changes will continue and ensure long-run peace and reconciliation with ethnic Kurds, especially in light of the uncertainties in Iraq.

Considering its fifteen year long war with ethnic separatism, Turkey has legitimate reasons for being concerned with the ethnic division of power, and for opposing an ethnic federation in the new Iraq. However, if overemphasized, this can lead to the overlooking of more important concerns and can undermine Turkey's and its allies' interests. ${ }^{39}$ Elevating the prevention of a Kurdish state to the level of Turkey's most important strategic interest in the region spreads the impression that Turkish and Kurdish interests are in fundamental conflict. It promotes the rival definition and should be expected to alienate Turkish Kurds. The key for regional peace and socioeconomic development is to ensure that the political configuration in Northern Iraq will be stable and will have friendly and cooperative relations with Turkey. This would enable Turkey to play a constructive regional role by fostering economic development and democracy. This would also serve American and European interests by

38. Ziya Önis, “After 9/11: The Importance of the EU Dimension,” Turkish Policy Quarterly, Vol. 2, No. 4 (Winter 2003).

39. For a critique in the press, Mehmet Ali Birand, "What Does Turkey Want to Do in Iraq?" Turkish Daily News, February 27, 2003. 
preventing the development of anti-American terrorism in Northern Iraq, and the EU would avoid an unstable border with Iraq if and when Turkey joins the union.

At the beginning of the war on Iraq, the media was ready to invoke the "ancient hatred" heuristic, once employed to describe the war in Bosnia, to describe the developments in Iraq. The New York Times wrote that "a large-scale Turkish intervention in Northern Iraq could ignite age-old ethnic hatreds between the Turks and Kurds [emphasis mine]." ${ }^{40}$ The author did not present any evidence regarding the age-old hatreds between Turks and Kurds, or why any of these sentiments could aptly be categorized as "ethnic." Describing Turkish-Kurdish relations according to the rival definition increases the polarization between the Iraqi Kurds and Turkmen, with negative consequences for democratization and Turkish-Kurdish relations within Turkey: the rival definition increases the possibility of large-scale identity shifts among Turkish Kurds, and can radicalize ethnic politics.

Turkey may have additional reasons not to overemphasize its rhetoric against Kurdish interests in Northern Iraq. Regional countries such as Iran and Syria oppose the establishment of a Kurdish state. Even if a Kurdish state becomes an actuality, the threat to Turkey's territorial integrity is limited because successful irredentist movements are rare. ${ }^{41}$ Moreover, Iraqi Kurds are economically dependent on Turkey and under any political configuration would be eager to maintain good relations with a powerful neighbor at the doorsteps of the EU. Successful economic development in Northern Iraq, thanks to American assistance and oil-wealth, would also have positive spill-over effects on the economy of the Turkish Southeast. However, the resolution of the economic problems and of the economically caused ethnic resentments in the Southeast requires much-enhanced developmental policies on Turkey's behalf. By comparison, discontented Iraqi Kurds are likely to seek to support secessionism in Turkey in order to regain the economic and political advantages they have secured since 1991. In sum, insofar as the possibility and negative ramifications for Turkey of Kurdish statehood are limited, any anti-Kurdish rhetoric by Turkey merely serves to promote the rival definition and to alienate Turkish Kurds.

The promotion of the compatible definition is an alternative political-discursive strategy that can be adopted by Turkey and its allies. In cooperation with the US and the EU, Turkey can play a key role in the post-war economic and democratic development of the region. Turkish-US talks can include projects whereby Turkey can use part of the 8.5 billion US credit as compensation for the war on Iraq toward developmental projects in Northern Iraq. From the point of view of the Turkish-Kurdish relations, a key issue here is the nature of such projects. They should create mutually beneficial social-economic relations and mutual dependence between Turkey, and the Iraqi Kurds and other ethnic groups. Such projects can promote trust and discourage hostility between the parties and thus contribute to friendly relations as the Yumurtalik oil pipe-line did for Iraq and Turkey for years. Turkey can also play important roles

40. Dexter Filkins, "Turkey Expected to Vote on G.I. Presence Tuesday," February 23, 2003.

41. Among others, Stephen M. Saideman and R. William Ayres, "Determining the Causes of Irredentism," The Journal of Politics, Vol. 62, No. 4 (November 2000), pp. 1126-1144. 
in the training of the Iraqi security forces and in the Iraqi judiciary's adjustment to a democratic system.

One limitation Turkey faces in promoting the compatible definition is the lack of effective representation of diverse Kurdish interests within Turkey. Most Kurdish spokespersons have limited credibility on behalf of the larger Turkish population because of their links, or overlapping constituencies, with the PKK. ${ }^{42}$ Popular sentiments against Öcalan and the PKK-KADEK make it unlikely that any Turkish government can venture to deal with such actors as interlocutors for reconciliation and further political liberalization. ${ }^{43}$

Another limitation is the difficulties of reconciliation with the PKK constituency. Militants inside and outside Turkey, especially guerillas who lived for years in extreme circumstances and in isolation from the rest of society, and PKK members outside Turkey, are especially apt to have developed hardened beliefs regarding the incompatibility of the Turkish and Kurdish identities and interests. ${ }^{44}$ While one cannot expect them to change their beliefs overnight, Ankara can seek feasible ways of encouraging their re-integration with the Turkish society. A US-prodded bill in August 2003, which offered partial-amnesty for PKK militants, has so far been a failure.

The timing of any state-led reforms affecting ethnic Kurds is also critical. If the reforms are interpreted as opportunistic or reluctant moves in response to developments in Iraq, they may actually reduce ethnic Kurds' trust in the government's good will and promote the rival definition. To be successful, policies promoting the compatible definition should be interpreted as such, and thus should precede political expediency and reflect a long-term strategy and intentions.

42. Interview with Tuncer Bakirhan, leader of DEHAP. Mehmet Ali Birand, "Is Dehap's Young Chairman Any Different?" Turkish Daily News, June 25, 2003.

43. For a counterargument, see Robins, pp. 79-91.

44. For an informative report, Kadri Gürsel, Dagdakiler: Bagok'tan Gabar'a 26 Gün [Those in Mountains: 26 Days, from Bagok to Gabar], (Istanbul: Metis Yayinlari, 1996). 